\title{
Coexistence of Major Complications in Pancreatic Pseudocyst: Case report
}

\author{
Ömer Fatih Nas ${ }^{1}$, Murat Pekgöz², Emre Ökeer ${ }^{1}$, Cüneyt Erdoğan ${ }^{1}$, Gürsel Savcl ${ }^{1}$, Selim Gürel ${ }^{2}$
}

\begin{abstract}
Pancreatic pseudocyst is the most common cystic lesion of the pancreas seen following acute and chronic pancreatitis in $2-10 \%$ and $10-30 \%$, respectively. Imaging findings vary depending on the age and severity of the attack. Infection, hemorrhage and rupture are the most frightening complications. The possibility of spontaneous recovery is considerably low. A 63-year old male patient who has history of longstanding alcohol consumption presented to the emergency department with complaints of abdominal pain. On computerized tomography (CT), an encapsulated and round peripancreatic collection with a size of approximately $8.5 \times 7.5 \mathrm{~cm}$ was detected in pancreatic head. In the literature, no article is published mentioning coexistence of complication such as infection, hemorrhage and rupture. We present the association of these three complications observed in our case. J Clin Exp Invest 2016; 7 (2): 203-206
\end{abstract}

Key words: Pancreatic pseudocyst, infection, hemorrhage, rupture

\section{Pankreatik Psödokistte Büyük Komplikasyonların Birlikteliği: Olgu Sunumu}

\section{ÖZET}

Pankreatik psödokist, akut pankreatitlerde 2-10\%, kronik pankreatitlerde ise 10-30\% görülebilen pankreasın en sık kistik lezyonlarıdır. Görüntüleme bulguları yaş ve atağın şiddetine bağlı olarak değişir. İnfeksiyon, hemoraji ve rüptür en çok korkulan komplikasyonlardır. Spontan iyileşme olasılığı oldukça düşüktür. 63 yaşında kronik alkol kullanımı olan erkek hasta acil servise karın ağrısı şikayeti ile başvurdu. Bilgisayarlı tomografide (BT) pankreas başında yaklaşık $8,5 \times 7,5 \mathrm{~cm}$ çapında enkapsüle ve yuvarlak psödokist ve peripankreatik sıvı izlendi. Literatürde infeksiyon, hemoraji ve rüptürün birlikte olduğu herhangi bir yayın mevcut değildir. Makalemizde bu üç komplikasyonun beraber görüldüğü bir vaka sunulmaktadır.

Anahtar kelimeler: Pankreatik psödokist, infeksiyon, hemoraji, rüptür

\section{INTRODUCTION}

Pancreatic pseudocyst is the most common cystic lesion of the pancreas frequently observed as a result of complication of acute and chronic pancreatitis or due to bland pancreatic trauma or surgery. Secondary infection of pseudocyst carries a high risk of morbidity and mortality that is why needs urgent treatment. However, the distinction of infected pseudocyst from pancreatic abscess or uncomplicated simple pseudocyst can not be easily made without clinical information [1]. Pseudocyst that persist longer than 6 weeks with a size of larger than $6 \mathrm{~cm}$ in symptomatic patients should be treated. Infection, hemorrhage or rupture may develop in untreated patients [2]. In this article, the association of the major complications of pseudocyst in a patient with chronic pancreatitis is presented.

\section{CASE REPORT}

A 63-year old male patient who has history of longstanding alcohol consumption for 35 years and diagnosis of chronic pancreatitis for 13 years presented to the emergency department with complaints of abdominal pain. An abdominal distension and extensive tenderness in the epigastric area were detected on physical examination. His previous acute attacks of pancreatitis in his history directed clinicians to a new attack. On computerized tomography (CT), an encapsulated and round peripancreatic collection with a size of approxi-

\footnotetext{
${ }^{1}$ Department of Radiology, Medical School, Uludağ University, Bursa, Turkey

${ }^{2}$ Department of Gastroenterology, Medical School, Uludağ University, Bursa, Turkey
}

Correspondence: Murat Pekgöz,

Uludağ University, Medical School, Department of Gastroenterology, Görükle, Bursa, Turkey Email: mesculape@hotmail.com Received: 04.04.2016, Accepted: 15.04.2016

Copyright @ JCEI / Journal of Clinical and Experimental Investigations 2016, All rights reserved 
mately $8,5 \times 7,5 \mathrm{~cm}$ was detected in pancreatic head (Figure 1).

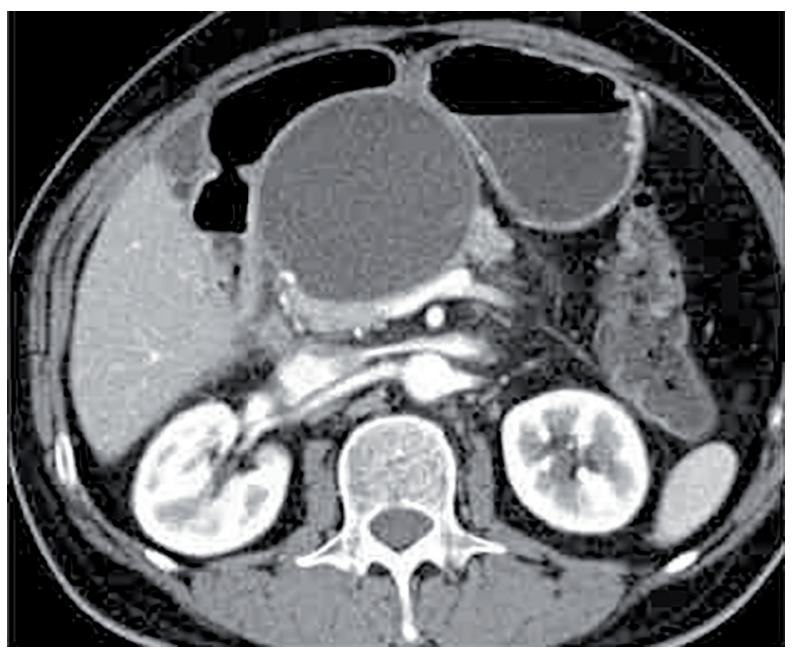

Figure 1. CT appearance: CT appearance of a round pseudocyst with a dimension of approximately $8.5 \times 7.5 \mathrm{~cm}$ in the pancreatic head

An urgent medical treatment was started after hospitalization. In the follow-up, while abdominal tenderness and pain regressed, epigastric distension persisted. Leukocytosis and persistence of high level of C-reactive protein despite two-weeks antibiotherapy directed us to the possibility of pseudocyst infection. Percutaneous catheter drainage following fine needle aspiration which yielded infected content was performed by interventional radiology. Approximately $1000 \mathrm{ml}$ of purulent fluid was drained during 48 hours which returned to fresh hemorrhagic drainage with simultaneous hematemesis.

An urgent endoscopy showed external compression extending from the anterior aspect of duodenal bulbus and active hemorrhagic ulcer in duodenal bulbus. The lumen was completely obstructed due to external compression of the mass which prevented the endoscope to proceed further segments. An endoscopic intervention failed stopping hemorrhage. Digital subtraction angiography (DSA) of celiac and superior mesenteric arterial system showed vessel injury in the gastroduodenal artery with contrast extravasation (Figure 2). Embolization therapy was decided to be performed as following technique; a microcatheter was passed into the superior mesenteric artery by way of anterior pancreatico-duodenal arcuate distal to hemorrhage in the gastroduodenal artery. Coil embolization was performed to the gastroduodenal artery from distal to proximal including the anterior pancreatico- duodenal arcuate (Figure 3). After coil embolization no contrast extravasation or hemorrhage was observed in control angiograms.

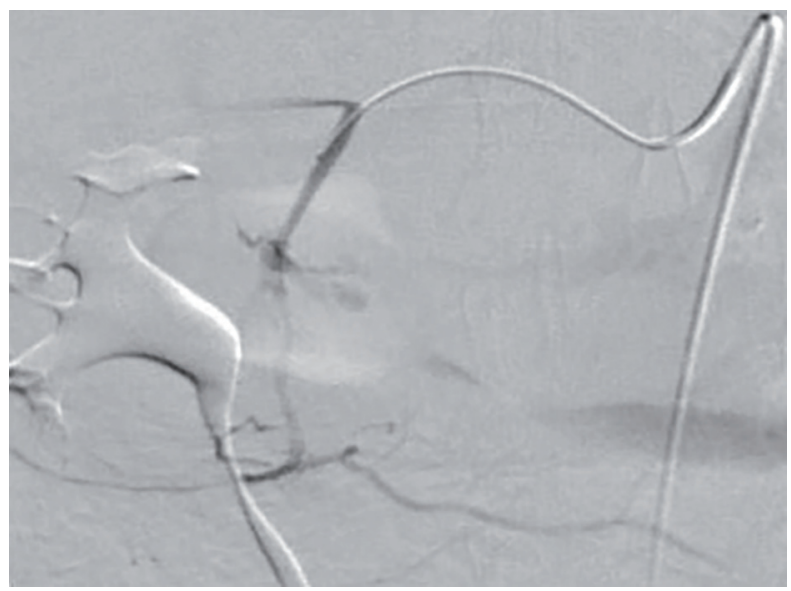

Figure 2. Image of digital subtraction angiography: Selective celiac digital subtraction angiography reveals vessel injury in the gastroduodenal artery with contrast extravasation and retrograde supply of the hemorrhage in the gastroduodenal artery from the superior mesenteric artery by way of the anterior pancreatico-duodenal arcuate

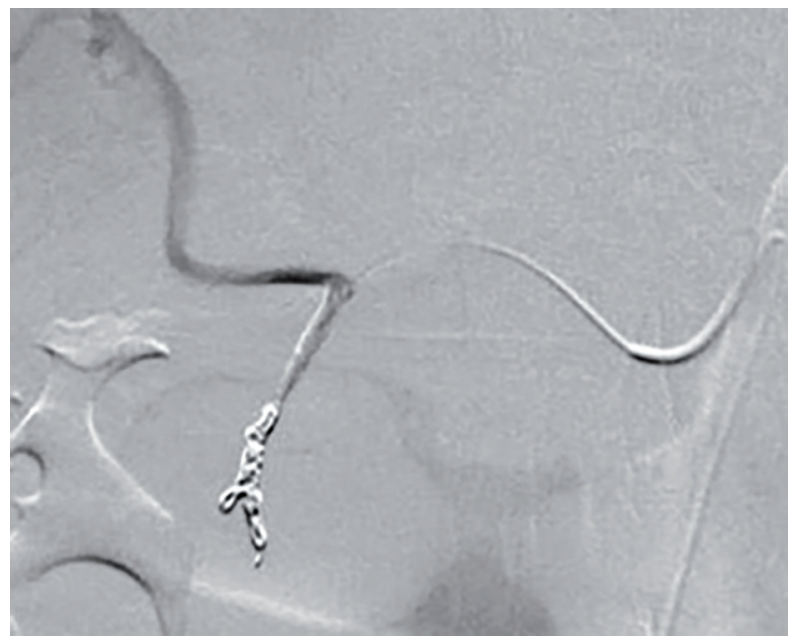

Figure 3. Image of coil embolization: Passage to the superior mesenteric artery distal to the hemorrhage in the gastroduodenal artery by way of the anterior pancreatico-duodenal arcuate using a microcatheter and DSA images after coil embolization in the gastroduodenal artery from distal to proximal including the anterior pancreatico-duodenal arcuate way.

The patient remained stable during follow-up period. The control CT examination revealed air densities in the pseudocyst cavity that was fistulized into the duodenal bulbus with extensive amount of free fluid 
within the abdominal cavity. The control gastroscopic examination showed the passage from the bulbus to the second part of the duodenum was normal with infected pseudocyst containing fibrinoid remnants, and necrotic materials with a $2 \mathrm{~cm}$ diameter fistula anterior face of the bulbus (Figure 4). The patient was discharged with gradual clinical recovery in four weeks.

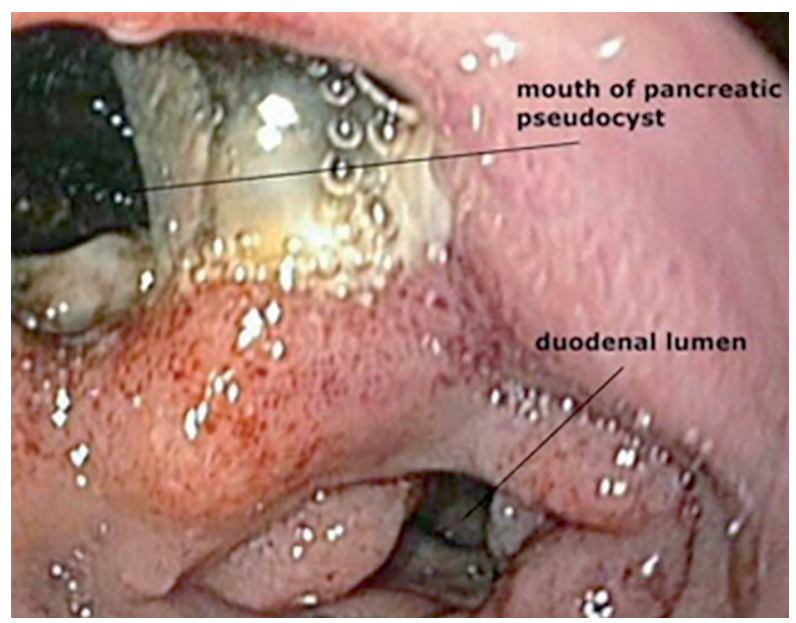

Figure 4. Endoscopic examination: Gastroscopic examination shows normal appearance of duodenal lumen and infected pancreatic pseudocyst containing fibrinoid remnants, hematin remnants and necrotic materials with a mouth having a diameter of $2 \mathrm{~cm}$ opening to the anterior face of the bulbus.

\section{DISCUSSION}

Pancreatic pseudocyst is the most common non-neoplastic cystic lesion of the pancreas which is associated with pancreatitis or trauma [3]. Infection, hemorrhage and rupture are the most frightening complications [4].

Drainage of pseudocysts by either surgical or radiological approach is suggested to prevent these complications [5], however this approach is not a routine practice. Percutaneous drainage is performed in cases with no response to analgesia or findings favor suspicious for infection are present [6]. Pseudocyst hemorrhage is a rare complication [7]. Although it is observed in less than $\% 5$ of the patients, it has a mortality above $40 \%$ [8]. The most common reason of hemorrhage is digestion of the artery walls in the peripancreatic arteries and pseudoaneurisms in the pancreatic bed by proteolytic enzymes [8]. Hemorrhage may originate from the splenic artery (47\%), gastroduodenal artery (17\%) and anterior pacreatico-duodenal artery (16\%). Exceptionally, hemorrhages originating from the superior mesenteric artery or hepatic artery may occur [7]. We have witnessed abdominal pain and a suspicion of clinical infection in our case. Therefore, drainage catheter was placed by percutaneous approach that proved the fluid was infected. Hemorrhage into the pseudocyst in our patient was found be originated from the gastroduodenal artery. Early diagnosis is necessary in situations that hemorrhage developed into the pseudocyst. Digital subtraction angiography is accepted as the most sensitive imaging method during active bleeding which also shows the bleeding site. An angiographic embolization is recommended as the first-line therapy in hemodynamically stable patients [7]. We performed coil embolization successfully to the gastroduodenal artery in the same session as the first-line option.

The spontaneous perforation and/or fistulization of pancreatic pseudocysts is observed with a rate below 3\%. Spontaneous rupture of pseudocysts occurs into the structures including stomach, duodenum, bile duct, renal collecting system, colon and bronchi. Spontaneous rupture of pancreatic pseudocyst into visceral organs is observed rarely [9]. Our case had spontaneous fistulization into the duodenal bulbus. Pseudocyst is treated with drainage. Although surgical approach is the preferred treatment modality, various non-surgical minimally invasive techniques such as radiological percutaneous aspiration, percutaneous catheter drainage, endoscopic transgastric drainage and endoscopic transpapillary procedures are considered appropriate [10]. Infection, hemorrhage and rupture are the major complications of pancreatic pseudocyst. However, all these complications seen in a single case is not reported.

Declaration of Conflicting Interests: The authors declare that they have no conflict of interest.

Financial Disclosure: No financial support was received.

\section{REFERENCES}

1. Kim YH, Saini S, Sahani D, et al. Imaging diagnosis of cystic pancreatic lesions: pseudocyst versus nonpseudocyst. RadioGraphics. 2005;25:671-85.

2. Jusoh AC, Hassan J, Nor RM, et al. Combined laparoscopic cholecystectomy and drainage of pancreatic pseudocyst: a case report and review of current management. Med J Malaysia. 2013;68:273-4.

3. Kucera JN, Kucera St, Perrin SD, et al. Cystic lesions of the pancreas: radiologic-endosonographic correlation. Radiographics.2012;32:283-301. 
4. Maule WF, Reber HA. Diagnosis and management of pancreatic pseudocysts, pancreatic ascites and pancreatic fistulas. In: Go VLW, Dimagno EP, Gardner JD, et al editors. The Pancreas: Biology, Pathobiology and Disease. New York: Raven Press; 1993:741-750.

5. Tuboku-Metzger VR, Seenath MM, Tan LC. Peritonitis secondary to traumatic duodenal laceration in the presence of a large pancreatic pseudocyst: a case report. J Med Case Rep. 2011;26:528.

6. Lee MJ, Wittich GR, Mueller PR. Percutaneous intervention in acute pancreatitis. RadioGraphics. 1998;18:711-24.

7. Bouassida M, Benali M, Charrada H, et al. Gastrointestinal bleeding due to an erosion of the superior mesenteric ar- tery: an exceptional fatal complication of pancreatic pseudocst. Pan Afr Med. 2012;12:62.

8. Levin DC, Eisenberg H, Wilson R. Arteriography in the evaluation of pancreatic pseudocysts. Am J Roentgenol.1977;129:243-8.

9. Somani PO, Jain SS, Shah DK, et al. Uncomplicated spontaneous rupture of pancreatic pseudocyst into stomach: A case report. World J Gastrointest Endosc. 2013;16:461-4.

10. Shimizu S, Morisaki T, Noshiro H, et al. Laparoscopic cystogastrostomy for pancreatic pseudocyst: a case report. JSLS. 2000;4:309-12. 